\title{
The Effect of Locus of Control Training on EFL Students' Reading Comprehension
}

\author{
Nejabati, Najva \\ Islamic Azad University, Science and Research Branch, Tehran, Iran \\ Tel: 98-91-6642-1611_E-mail: Najva_Nejabati@yahoo.com
}

Received: January 5, 2014 Accepted: January 27, 2014 Published: January 27, 2014

doi:10.5296/ijele.v2i1.4992 URL: http://dx.doi.org/10.5296/ijele.v2i1.4992

\begin{abstract}
The present study examined the effect of locus of control training on EFL students' reading comprehension. Upper intermediate undergraduate EFL learners $(\mathrm{N}=24)$ were assigned to experimental and control groups. The experimental group received training on locus of control attribute and how to use locus of control construct on their reading comprehension in a month, 8 sessions and 16 hours, while control group did not received any instruction. Two parallel multiple- choice TOEFL reading tests were used to measure the effects of self-regulated learning strategy training. The results of independent sample t-test suggested that experimental group performed significantly better on posttest administration of the reading test.
\end{abstract}

Keywords: locus of control, attribution, reading comprehension, EFL Students, Attributional style, Social learning theory, Reinforcement, Expectancy 


\section{Introduction}

According to the idea of Williams and Burden (1997), learning does not take place in a vacuum. Environmental, social, political, and many other learner-external factors interact in complex ways to determine learning outcome. Learning is a complex process influenced by individual characteristics, such as learning strategies, the content of material to be learned, as well as the learning setting. Much recent debates has centered on students`conceptions of learning, which is believed to be influenced by their competencies, past experiences, expectations and beliefs about the level of perceived control they can perform about learning. This sense of personal control over the educational process is known as locus of control (LOC) which is the most significant factor in arousing and maintaining individuals' interest and engagement in learning activities (Salmaninodoushan,2012).

Locus of Control is rooted in social learning theory. Social learning theory asserts that an individual learns on the basis of his or her background of reinforcement that is the reward or praise given by others in response to behavior (Baron \& Byrne, 2002). The premise of social learning theory is that an individual's actions are predicted on the basis of the individual's expectations for reinforcement, the perceived value of reinforcement and the situation in which the individual find himself (Kormanik \& Rocco, 2009). Reinforcement acts to enhance the expectancy that a particular behavior or event will be followed by the reinforcement in the future. Expectancy is equal to the value of reinforcement, and requires that the individual value the outcome, have self-efficacy, understand and trust the reward system and avoid negative or unacceptable outcome (Lawlewr, 1973).

According to Rotter (1996) locus of control indicates how a person believes about control over life events, and refers to whether individuals relate their success or failure to their own behavior or an external factor. In the context of foreign language learning, learners hold different beliefs about their success or failure in the foreign language program. A student who has a poor performance in a foreign language program may ascribe his failure to the difficulty of language, the attitude of the foreign language instructor, inadequacy on teaching method adopted by the instructor. These beliefs invariably determine generalized expectations concerning where control over subsequent events resides (Manger, 2002)

Attribution according to Baron and Byrne (2002) refers to our efforts to understand the causes behind other's behavior and on some occasions, the causes behind our behavior too. Rotter (1990) also distinguished between locus of control and Attributional style in that the former is a concept linked with expectancies about the future, while the latter is a concept linked expectations for past outcomes.

In order to investigate the potential impact of locus of control training on EFL students' reading comprehension the following research question can be formulated.

1. Does locus of control training have any statistically significant effect on EFL students reading comprehension? 
In order to answer the above mentioned research question an 8 sessions sequence of treatment in locus of control training in EFL reading class was performed.

\section{Method}

A total number of 24 upper-intermediate EFL students of English translation studying at university (Islamic Azad University) participated in this study chosen among 45 students. These participants included males and females with and age range of 20-26. A paper-based Test of English as a Foreign Language (TOEFL) was administered prior to the study to make sure that all the participants are the same level of language proficiency. So, among the students who took the TOEFL test, the researcher selected 24 who scored one standard deviation above and one standard deviation below the mean score were chosen as participants.

For the sake of this study, the students attended a total of 8 sessions. The classes met for 2 hours twice a week over four weeks. It should be noted that all sessions were taught by the same teacher-researcher in the same way. The treatment period was concentrated on strengthening the students' internal locus of control while the reading comprehension skill was taught. During the treatment the students were trained to say positive things to themselves, like I am good at learning language, I know how to do this sort of task, I work hard, this task is easy, I comprehend well when I am read, I do the book's exercises after each lesson perfect. In this step, it was tried to help students develop positive attitudes towards their ability in success in reading comprehension course and learn it perfectly. Also, the students were taught to believe in their own ability to handle the tasks and learn completely. The teacher encouraged learners during reading lesson in order to train locus of control construct and helped the students identify cognitively and socially their own attitudes towards language learning, especially reading comprehension, and find their strength and weaknesses. The students were taught how to develop their own individual plans for learning reading comprehension and take responsibility for carrying out their own learning plans. They also learned how to take responsibility and receiving different tips and hints and taking part in tasks collaboratively.

\section{Data Analysis}

The participants in the aforementioned university were administered the reading TOEFL test, and TOEFL homogenized test. First, the homogenization test and then reading test were administered. After that, the treatment was executed just for the experimental group. After the treatment, the posttest administration of the reading test was done. The posttest reading test was a parallel form of the pretest reading TOEFL test. The participants were assured that their identities and responses would be kept confidential. In order to determine the possible effects of locus of control training on EFL reading comprehension, the mean of the two groups were compared through an independent sample t-test. Spss version 19 for Windows was used for all statistical tests.

\section{Results and Discussion}

To investigate the effects of locus of control training on EFL reading comprehension, a kind 
of independent sample t-test was run between the mean scores of the participants in pretest and posttest administration of the reading tests. Table 1 and 2 show the results of independent sample t-test between control and experimental groups in pretest and posttest.

Table 1. Independent sample t-test between control and experimental groups in pretest

\begin{tabular}{|c|c|c|c|c|c|c|c|c|c|c|}
\hline & \multicolumn{2}{|c|}{$\begin{array}{c}\text { Levene's Test } \\
\text { for Equality of } \\
\text { Variances } \\
\end{array}$} & \multicolumn{7}{|c|}{ t-test for Equality of Means } \\
\hline & & \multirow[b]{2}{*}{$\mathrm{F}$} & \multirow[b]{2}{*}{ Sig. } & \multirow[b]{2}{*}{$\mathrm{T}$} & \multirow[b]{2}{*}{ df } & \multirow{2}{*}{$\begin{array}{l}\text { Sig. } \\
\text { (2-tail } \\
\text { ed) }\end{array}$} & \multirow{2}{*}{$\begin{array}{c}\text { Mean } \\
\text { Differ } \\
\text { ence }\end{array}$} & \multirow{2}{*}{$\begin{array}{l}\text { Std. } \\
\text { Error } \\
\text { Differ } \\
\text { ence }\end{array}$} & \multicolumn{2}{|c|}{$\begin{array}{c}95 \% \\
\text { Confidence } \\
\text { Interval of the } \\
\text { Difference }\end{array}$} \\
\hline & & & & & & & & & Lower & Upper \\
\hline \multirow{4}{*}{$\begin{array}{l}\text { ReadingLOC } \\
\text { Control }\end{array}$} & Equal & .007 & .933 & .281 & 22 & .781 & .2500 & .8901 & -1.595 & 2.095 \\
\hline & $\begin{array}{l}\text { variances } \\
\text { assumed }\end{array}$ & & & & & & 0 & 1 & 98 & 98 \\
\hline & Equal & & & .281 & 21.77 & .781 & .2500 & .8901 & -1.597 & 2.0971 \\
\hline & $\begin{array}{l}\text { variances not } \\
\text { assumed }\end{array}$ & & & & 0 & & 0 & 1 & 11 & 1 \\
\hline
\end{tabular}

Table 2. Independent sample t-test between control and experimental groups in posttest

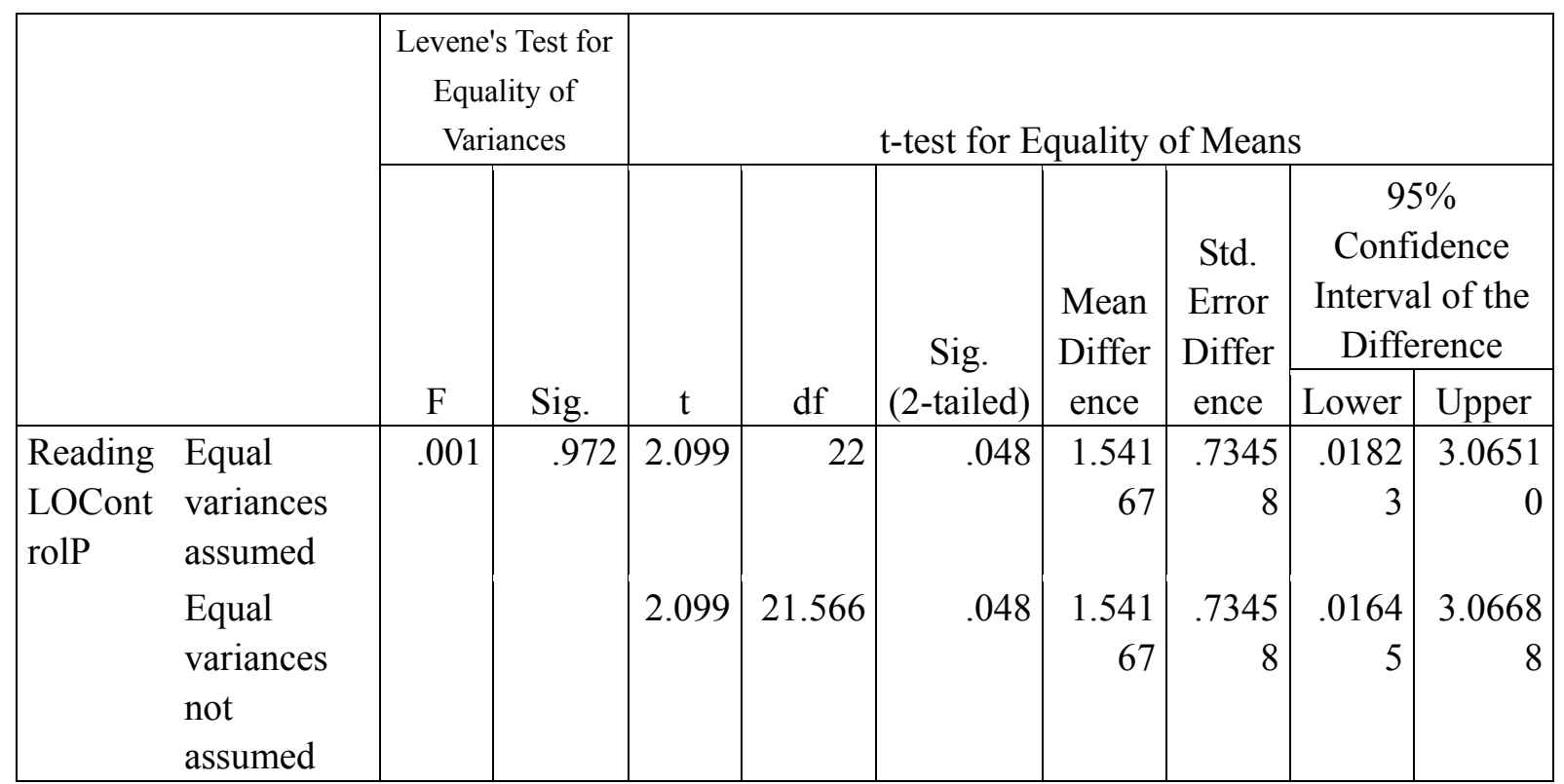

As the results indicated that there is statistically significant difference between mean scores of the two experimental and control group in posttest administration $(\mathrm{P}=.048<.05)$. So, it can 
be concluded that locus of control training has effects on EFL learners reading comprehension. Also, the paired sample t-test of questionnaire in the two administrations for experimental group shows that there is a significant difference $(\mathrm{P}=.002<.05)$ between mean score of the learners in experimental group. So, it can be concluded that learners in locus of control training have progressed after the treatment period.

\section{Conclusion}

Being able to use locus of control training in a positive way is crucially important to the process of developing reading skill. The results of this study demonstrated that students' reading proficiency improved significantly over one month. Like the findings of others (Soleiman-nejad \& Shahara, 2001; Ghonsooly \& Elahi shirvani, 2011; Heidari \& Khorasaniha, 2013) training in locus of control can have effects on improvement of academic achievement especially in reading comprehension and there is relationship between locus of control and achievement in reading comprehension.

The findings of the present study can help teachers to teach reading comprehension more effectively as an important skill, and using locus of control training as an effective factor in developing reading comprehension and also general achievement. Besides teachers, syllabus designers can use the findings of this study in providing materials which contain proper contents to language learners and teachers, design exercises and deploy this training to achieve their goals which is reading comprehension.

Reading is of course an important issue to many EFL learners since it is one of the four skills they require to achieve if they wish to be good learners. With the changes happening in the world today, students are considered as lifelong learners and reading is one of the skills they need to this end. Through reading, learners can learn new information, clarify them, and evaluate what they have achieved. One of the major challenges that many teachers face is how to teach and deal with reading texts. Their focus is mostly on new vocabularies or the grammatical structures of the text which are important factors in comprehending but not sufficient ones. What complements their work would be acquiring new strategies which makes learners interested and more active in this activity and lead them to better comprehension and also lifelong learners. Therefore, by deploying self- regulated learning strategies and training in locus of control, teachers can mostly overcome the challenge of how to teach and deal with the reading skill.

To this end, locus of control training as a new procedure in teaching should be emphasized in teachers' work as effective factor developing reading comprehension and also general achievement. Beside teachers, there are other factors which affect the learning process significantly; syllabus designers and materials developers also play an important role in this regard. They provide teaching materials which contain proper contents to language learners, design exercises and deploy these strategies to achieve their goal which is reading comprehension. They should provide handbooks for teachers which contain guidelines for efficient teaching through locus of control training. This will lead teachers to teach effectively and learners to be more independent in the language learning process. 


\section{References}

Baran, R., \& Byrne, D. (2002). Social psychology. London: Hall International, INC.

Ghonsooly, B., \& Elahi, M. (2010). Validating locus of control : questionnaire and examining its relation to general English achievement. The journal of teaching language skills (JTLS), 1(2), 117-143.

Heidari, F., \& Khorasaniha, N. (2013). Delving in to the relationship between LOC, MI, and Reading proficiency. Journal of language teaching and research, 1(4), 89-96.

Kormanik, M. T., \& Roco, S. (2009). Internal versus external locus of control: A review of locus of control construct. Human resource development review, 1(4), 1-17. http://dx.doi.org/10.1177/15344.

Lawler, E. (1973). Motivation in Work Organization, Books Cole, Monterey, California.

Manger, T., \& Eikeland, O. J. (2002). Effects of social cognitive training on students' locus of control. Social psychology international, 23(1), 342-354. http://dx.doi.org/10.1177/01430343002023003237

Rotter, J. (1990). Internal versus external locus of control. American Psychology Association, $45,489-493$.

Salmaninodoushan, M. A. (2012). The impact of locus of control on language achievement. International Journal of Language Studies, 6(1), 123-130.

Soleymannejad, A., \& Shaharai, M. (2002). The relationship between locus of Control and self-regulated learning with academic achievement. Journal Of Psychology and Education, 2(1), 175-198.

Williams, M., \& Burden, R. (1997). Psychology for language teachers. Cambridge: Cambridge University Press.

\section{Copyright Disclaimer}

Copyright reserved by the author(s).

This article is an open-access article distributed under the terms and conditions of the Creative Commons Attribution license (http://creativecommons.org/licenses/by/3.0/). 